\title{
Front Matter: Volume 11035
}

, "Front Matter: Volume 11035," Proc. SPIE 11035, Optics Damage and Materials Processing by EUV/X-ray Radiation VII, 1103501 (9 July 2019); doi: $10.1117 / 12.2535651$

SPIE. Event: SPIE Optics + Optoelectronics, 2019, Prague, Czech Republic 


\title{
PROCEEDINGS OF SPIE
}

\section{Optics Damage and Materials \\ Processing by EUV/X-ray Radiation VII}

\author{
Libor Juha \\ Saša Bajt \\ Stéphane Guizard \\ Editors
}

1-3 April 2019

Prague, Czech Republic

Sponsored and Published by

SPIE 
The papers in this volume were part of the technical conference cited on the cover and title page. Papers were selected and subject to review by the editors and conference program committee. Some conference presentations may not be available for publication. Additional papers and presentation recordings may be available online in the SPIE Digital Library at SPIEDigitallibrary.org.

The papers reflect the work and thoughts of the authors and are published herein as submitted. The publisher is not responsible for the validity of the information or for any outcomes resulting from reliance thereon.

Please use the following format to cite material from these proceedings:

Author(s), "Title of Paper," in Optics Damage and Materials Processing by EUV/X-ray Radiation VII, edited by Libor Juha, Saša Bajt, Stéphane Guizard, Proceedings of SPIE Vol. 11035 (SPIE, Bellingham, WA, 2019) Seven-digit Article CID Number.

ISSN: 0277-786X

ISSN: 1996-756X (electronic)

ISBN: 9781510627369

ISBN: 9781510627376 (electronic)

Published by

SPIE

P.O. Box 10, Bellingham, Washington 98227-0010 USA

Telephone +1 3606763290 (Pacific Time) · Fax +1 3606471445

SPIE.org

Copyright @ 2019, Society of Photo-Optical Instrumentation Engineers.

Copying of material in this book for internal or personal use, or for the internal or personal use of specific clients, beyond the fair use provisions granted by the U.S. Copyright Law is authorized by SPIE subject to payment of copying fees. The Transactional Reporting Service base fee for this volume is $\$ 18.00$ per article (or portion thereof), which should be paid directly to the Copyright Clearance Center (CCC), 222 Rosewood Drive, Danvers, MA 01923. Payment may also be made electronically through CCC Online at copyright.com. Other copying for republication, resale, advertising or promotion, or any form of systematic or multiple reproduction of any material in this book is prohibited except with permission in writing from the publisher. The CCC fee code is 0277$786 \times / 19 / \$ 18.00$.

Printed in the United States of America by Curran Associates, Inc., under license from SPIE.

Publication of record for individual papers is online in the SPIE Digital Library.

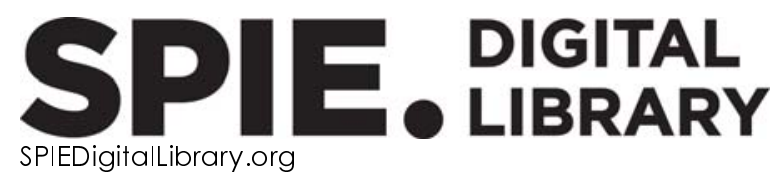

Paper Numbering: Proceedings of SPIE follow an e-First publication model. A unique citation identifier (CID) number is assigned to each article at the time of publication. Utilization of CIDs allows articles to be fully citable as soon as they are published online, and connects the same identifier to all online and print versions of the publication. SPIE uses a seven-digit CID article numbering system structured as follows:

- The first five digits correspond to the SPIE volume number.

- The last two digits indicate publication order within the volume using a Base 36 numbering system employing both numerals and letters. These two-number sets start with 00, 01, 02, 03, 04, 05, 06, 07, 08, 09, 0A, OB ... 0Z, followed by 10-1Z, 20-2Z, etc. The CID Number appears on each page of the manuscript. 


\section{Contents}

$\begin{array}{ll}\vee & \text { Authors } \\ \text { vii } & \text { Conference Committee }\end{array}$

FACILITIES AND THEIR OPTICS

1103505 Table-top focused EUV optical system with high energy density and its application on EUV damage tests [11035-4]

ULTRASHORT PULSES IN ACTION

1103507 Ultrafast dynamics of water exposed to XFEL pulses (Invited Paper) [1 1035-6]

SHORT PULSES IN ACTION

$110350 G \quad$ Target return current in low-intensity laser target interaction [1 1035-15]

DAMAGE AND STRUCTURING

$11035 \mathrm{Ol}$ Tuning the functional properties of $\mathrm{YBa}_{2} \mathrm{Cu}_{3} \mathrm{O}_{7-\delta}$ by synchrotron $\mathrm{x}$-ray irradiation [1 1035-17]

$110350 \mathrm{~J} \quad$ Actinic damage of Y/Mo multilayer Bragg-optics in a tabletop extreme ultraviolet laser (Invited Paper) [11035-18]

11035 OK Nanostructuring of PMMA, GaAs, SiC and Si samples by focused XUV laser beam [1 1035-19]

\section{INSTRUMENTATION AND METHODS}

11035 OM Near-edge x-ray absorption fine structure spectroscopy with laser plasma sources of soft x-ray radiation [1 1035-21]

11035 ON Photoluminescence properties and characterization of LiF-based imaging detector irradiated by $10 \mathrm{keV}$ XFEL beam [11035-22] 
1103500 Aging of Al thin film extreme ultraviolet filters [1 1035-23]

THEORY AND SIMULATIONS

$110350 Q \quad$ Modeling warm dense matter formation within tight binding approximation (Invited Paper) [11035-25]

11035 OR Modelling extreme ultraviolet ablation interactions (Invited Paper) [1 1035-26] 


\section{Authors}

Numbers in the index correspond to the last two digits of the seven-digit citation identifier (CID) article numbering system used in Proceedings of SPIE. The first five digits reflect the volume number. Base 36 numbering is employed for the last two digits and indicates the order of articles within the volume. Numbers start with 00, 01, 02, 03, 04, 05, 06, 07, 08, 09, OA, 0B...0Z, followed by 10-1Z, 20-2Z, etc.

Agostino, Angelo, 01

Bartnik, A., OM

Bleiner, Davide, 0J

Bonfigli, F., ON

Bonino, Valentina, 0 I

Caleman, Carl, 07

Choukourov, A., OK

Cikhardt, Jakub, $0 G$

Dostál, Jan, OG

Duda, M., OM

Dudžák, Roman, OG

Fiedorowicz, H., OM

Fok, T., OM

Fretto, Matteo, ol

Frolov, Alexandr, OK, 00

Hartley, N. J., ON

Hoffer, Petr, 00

Huang, Qiushi, 05

Inubushi, Y., ON

Jönsson, $\mathrm{H}$. Olof, 07

Juha, Libor, $0 \mathrm{O}$

Klír, Daniel, OG

Koenig, M., ON

Kolacek, Karel, OK, 00

Krása, Josef, OG

Li, Wenbin, 05

Lolley, J. A., OR

Lukes, Petr, 00

Makarov, S., ON

Matsuoka, T., ON

Medvedev, Nikita, OQ

Mino, Lorenzo, ol

Montereali, R. M., ON

Nassisi, Vincenzo, OG

Nichelatti, E., ON

Östlin, Christofer, 07

Ozaki, N., ON

Pan, Liuyang, 05

Pfeifer, Miroslav, OG

Piccinini, M., ON

Pikuz, S., ON

Pikuz, T., ON

Prestipino, Carmelo, 01

Řezáč, Karel, OG

Sagae, D., ON

Schmidt, Jiri, OK, 00

Stelmashuk, Vitaliy, 00

Straus, Jaroslav, OK, 00

Tallents, G. J., OR
Timneanu, Nicusor, 07

Truccato, Marco, 01

Vincenti, M. A., ON

Wachulak, P., OM

Wang, Zhanshan, 05

Węgrzyński, Ł., OM

Wilson, S. A., OR

Xie, Chun, 05

Yabashi, M., ON

Yabuuchi, T., ON

Yi, Shengzhen, 05

Zhang, Zhe, 05

Zhang, Zhong, 05 
Proc. of SPIE Vol. 11035 1103501-6

Downloaded From: https://www.spiedigitallibrary.org/conference-proceedings-of-spie on 26 Apr 2023
Terms of Use: https://www.spiedigitallibrary.org/terms-of-use

lems or Use: hips:/Wwisplediglalbrary.orgems-of-use 


\title{
Conference Committee
}

\author{
Symposium Chairs
}

Bedrìch Rus, ELI Beamlines, Institute of Physics of the CAS, v.v.i. (Czech Republic)

Chris Edwards, STFC Rutherford Appleton Laboratory (United Kingdom)

Saša Bajt, Deutsches Elektronen-Synchrotron (Germany)

Ivo Rendina, Istituto per la Microelettronica e Microsistemi (Italy)

Honorary Symposium Chair

Erich Spitz, French Academy of Sciences, National Academy of Technologies (France), Advisor to Thales (France)

Conference Chairs

Libor Juha, Institute of Physics of the ASCR, v.v.i. (Czech Republic)

Saša Bajt, Deutsches Elektronen-Synchrotron (Germany)

Stéphane Guizard, CEA-DRF-IRAMIS, Laboratory des Solides Irradiés (France)

Conference Program Committee

Fred Bijkerk, University Twente (Netherlands)

Jaromír Chalupský, Institute of Physics of the ASCR, v.v.i.

(Czech Republic)

Henryk Fiedorowicz, Military University of Technology (Poland)

Jacek Krzywinski, SLAC National Accelerator Laboratory (United States)

Klaus Mann, Laser-Laboratorium Göttingen (Germany)

Tomáš Mocek, Institute of Physics of the ASCR, v.v.i. (Czech Republic)

Ladislav Pina, Czech Technical University in Prague (Czech Republic)

Jorge J. Rocca, Colorado State University (United States)

Michael Störmer, Helmholtz-Zentrum Geesthacht (Germany)

Philippe Zeitoun, Ecole Nationale Supérieure de Techniques

Avancées (France)

Beata Ziaja-Motyka, Deutsches Elektronen-Synchrotron (Germany) 


\section{Session Chairs}

1 Facilities and their Optics

Libor Juha, Institute of Physics of the CAS, v.v.i. (Czech Republic)

2 Ultrashort Pulses in Action

Jaromír Chalupský, Institute of Physics of the CAS, v.v.i. (Czech Republic)

3 Short Pulses in Action

Stéphane Guizard, CEA-DRF-IRAMIS (France)

4 Damage and Structuring

Saša Bajt, Deutsches Elektronen-Synchrotron (Germany)

5 Instrumentation and Methods

Josef Krasa, Institute of Physics of the CAS, v.v.i. (Czech Republic)

6 Theory and Simulations

Beata Ziaja-Motyka, Deutsches Elektronen-Synchrotron (Germany)

7 Summary and Discussion

Libor Juha, Institute of Physics of the CAS, v.v.i. (Czech Republic) 